\title{
灌溉取水の影響を考慮した 全球河川流量シミュレーション GLOBAL RIVER DISCHARGE SIMULATION TAKING INTO ACCOUNT IRRIGATION WATER INTAKE
}

\author{
花崎直太 ${ }^{1} \cdot y \operatorname{yl}_{\text {信次郎 }}^{2} \cdot$ 沖大幹 $^{3}$ \\ Naota Hanasaki, Shinjiro Kanae and Taikan Oki \\ 1学生会員 工修 東京大学生産技術研究所（干153-8505 東京都目黒区駒場4-6-1） \\ 2 正会員 工博 総合地球環境学研究所（广602-0878 京都市上京区高島町335） \\ 3正会員 工博 東京大学生産技術研究所（†153-8505 東京都目黒区駒場4-6-1）
}

\begin{abstract}
A global river discharge simulation is conducted taking into account irrigation water intake and reservoir operation. The monthly irrigation water demand is calculated globally by a modeling approach, and it is withdrawn from the river section in the same calculating cell. Four simulation runs (with/without irrigation intake $\times$ with/without reservoir operation) are compared, to clarify the effect of irrigation water intake on the river discharge simulation.

In the latter part, irrigation water demand and supply is assessed in monthly interval for nine basins in the world. The result suggests that the irrigation water intake significantly decreases the river discharge in specific period and affects the water resources in the whole river basin.
\end{abstract}

Key Words: Global river discharge simulation, Irrigation, Reservoir Operation

\section{1.はじめに}

灌溉用水は世界で年間 $2504 \mathrm{~km}^{3}$ 取水され、1753k $\mathrm{km}^{3}$ 消費 されると推定されている1)。これは年間総取水量 $3788 \mathrm{~km}^{3}$ の66\%、世界の河川流量 $40000 \mathrm{~km}^{3}$ の\%に当たる莫大な量 である゙。この灌溉用水取水は世界の河川流量にどのよ うな影響を及ぼしているのだろうか?また灌覞農地は全 耕作地の17\%に過ぎないが、そこから生産される食料は 全食料生産の $40 \%$ を占めている ${ }^{2}$ 。灌溉農業は世界の人口 増加と経済成長に伴う食料問題の鍵を握っているが、こ のための灌溉用水は持続的に取水できるのだろうか?

灌溉が広域の河川流量に与える影響について論じた研 究は数多く発表されている。Haddeland et al. (2004) は灌溉がColorado川とMekong川流域の水・熱収支に与え る影響を陸面過程モデルと河川流下モデルを利用して定 量的に評価しだ3。甲山ら（2004）は灌溉が淮河の上中 流域の水収支に与える影響を衛星リモートセンシングと 陸面過程モデルを利用して定量的に評価した4)。対象を 流域加全球一と扡大するための研究も数多く発表され ている。Döll and Siebert（2002）は灌溉農地分布デ一 夕、気象データ、作物要求水量モデルを利用し、 $0.5^{\circ} \times 0.5^{\circ}$ の空間解像度で世界の灌溉用水量を算定した5)。 Alcamo et al.（2003）はこの結果を取り入れ世界水資 源モデルを開発した6) 。このモデルでは河川取水と河川 流量が統合的に扱われるとされているが、論文中には灌 溉が世界の河川流量や水循環に与える影響について言及 されていない。

本研究の目的は以下の 3 つである。第 1 に灌溉取水を 考慮した全球河川流量シミュレーションをおこない、尒 球・流域の河川水収支に与える影響を定量的に示すこと である。第 2 に灌溉取水を考慮することで流量シミュ レーションの再現性が向上するか検討することである。 観測流量には灌涀取水の影響が含まれているので、モデ ルにこれらの要素を取り込めば理論上は計算值が観測值 に近づくはずである。第 3 に灌溉用水需要と灌溉取水の バランスを月単位で空間分布を含めて定量的に評価する ことである。既存の水資源アセスメントでは上流の取水 による流量の減少が考慮されず、また評価も年単位で行 われることが多かった。しかし灌泊取水は絶対量が多く 下流の河川流量への影響が無視できないこと、必要な時 期に必要な量が供給できることが重要であることから、 本研究では取水を考慮し、月単位での評価を試みる。 


\section{2. 方法}

\section{(1) モデル}

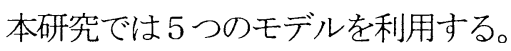

a) 全球河川流路網モデルTRIP

空間解像度 $1^{\circ} \times 1^{\circ}$ のデジタル河道網地図を持ち、同じ く空間解像度 $1^{\circ} \times 1^{\circ}$ のグリッド流出データを上流から下 流へ、流下による時間遅れを考慮しながら積算して河川 流量の計算を行う。TRIPは流下専用のモデルであり、降 雨流出過程は陸面過程モデルを用いて外部で計算される。

\section{b）農事暦推定モデル ${ }^{8)}$}

気温と河川流量の月データを点数化することにより、 1 年のうち最も農作業に適した期間を月単位で割り出す。 単純化のために 3 つの重要な前提を抒いている。(1)作物 の牛育期間は 5 ケ月とすること。栽培期間が 5 ケ月なの で二期作まで可能である。(2)月平均気温が $5{ }^{\circ} \mathrm{C}$ を下回る 月には作物が生育できないものとすること。(3)作付け種 は水稲とそれ以外の 2 種類とすること。水稲の作付けは インド東部から中国の淮河以南までの南〜東アジアとし、 地域で固定する。この地域では一期作も二期作も水稲が 栽培されるものとする。

\section{c）灌溉用水推定モデル}

b)で得られた作付け期間に対して、作物の理想的な牛. 長に必要な水量を計算する。これは可能蒸発散量に植物 の成長に応じて時間的に増減する作物倸数を乗じたもの から有効降雨量を引いた量である。単位面積あたりの需 要量に世界の灌溉面積の分布を乗じて求めた灌汯用水需 要量は表-1の通りである。

\section{表-1 灌溉用水需要}

\begin{tabular}{|l|r|l|l|}
\hline & 本研究 & $\begin{array}{l}\text { Döll and } \\
\text { Siebert 2002 }\end{array}$ & $\begin{array}{l}\text { Sh ik lomanov } \\
2000\end{array}$ \\
\hline 灌溉面積 $(106 \mathrm{~km} 2)$ & 2.54 & 2.54 & NA \\
\hline 灌溉用水需要A $(\mathrm{km} 3)$ & 1413 & 1091 & 1753 \\
\hline 灌溉用水需要B $(\mathrm{km} 3)$ & 2826 & 2452 & 2504 \\
\hline
\end{tabular}

表-1にある灌溉用水需要Aは作物の純要求量、Bは配水時 の損失などを考慮した取水量を指す。Döll and Siebert （2002）はモデルを利用した計算值、Shiklomanov（2000） は統計データを編集した值である。灌溉設備が未発達で あるほど、取水量は純要求量より大きくなる。

d）貯水池操作サブモデル ${ }^{8)}$

全球河川流路網モデルTRIPに貯水池操作を取り入れるた めの着脱可能な機能追加モジュールである。総貯水容量 10 億 $\mathrm{m}^{3}$ 以上の 500 の貯水池について、貯水容量、年平均 流量と貯水池の目的から操作ルールを推定し、ルールに そって放流・貯留の操作を行う。本研究では以下のよう に花崎ら (2004) とは異なる方法で操作ルールの設定を行 う。まずWRTによる牛活用水と丁.業用水の取水量の全球 分布データ9（1995年ベース、全球 $\left.0.5^{\circ} \times 0.5^{\circ}\right)$ とc)の
灌溉用水需要を足し合わせ、月別の全用水需要を計算し た。生活用水と下.業用水は年平均值しか入手できなかっ たので毎月一定量が取水されると仮定した。次に貯水池 の下流域の全用水需要を足しあわせ、貯水池ごとの下流 の需要変動パターンを得た。貯水池からは貯水池の主目 的に関わらず、この需要変動パターンに合わせた放流を 行うものとする。

\section{e）灌溉取水サブモデル}

全球河川流路網モデルTRTPに灌泊取水の効果を取り入 れるための着脱可能な機能追加モジュールである。c)で 計算された灌激用水需要Aを河川から取水し、その水は 全て蒸発散に使われるとみなす。実際に取水されるのは 灌溉用水需要Bにあたる量であるが、これは地下浸透や 河川への復流水を含んだ量であり、水収支を考えるトで 扱いが難しい。取水は下流への影響を無視し、その地点 で流量がゼロになるまで行われる。この量を「可能灌溉 取水量」と名づける。本研究では灌溉用水はすべて河川 水から取水されると仮定する。実際には世界の多くの地 域で地下水が市な灌溉用水供給源として使われているが、 陸域の水収支を計算する際に利用する陸面過程モデルが 地下水涵養を考慮せず、これに相当する水を河川への基 底流出として処理することから、本研究では地下水から の取水は河川からの取水に含めることにしている。TRIP では陸域全てのグリッドに対して流量のあるなしに関わ らず河道を割り当てていること、河道に入った基底流出 は取水以外に蒸発などで失われないと仮定していること から、乾燥地や乾季に行秃る地下水を利用した灌激に 対しても適用が可能だとみなした。

\section{（2）数值実験}

本研究では世界の河川流量に関する 4 つの数值実験を おこなう。TRTPに与える全球 $1^{\circ} \times 1^{\circ}$ のグリッド流出デー 夕は4つとも共通にGlobal Soil Wetness Project Phase 1 (GSWP1) で構築された世界の陸域の水文気象 データセット ${ }^{10}$ のうち、気象庁の陸面過程モデルSiBを 用いてオフライン計算されたものを利用した。計算期間 は1987年と1988年の 2 年分である。

\section{a) CTRL実験}

TRIPを利用して河川流量の計算を行ったものである。

\section{b) RSVR実験}

TRIPと貯水池操作サブモデルを利用して河川流量の計 算を行ったものである。

\section{c) INT実験}

TRIP と灌溉取水サブモデルを利用して河川流量の計算 を行ったものである。

\section{d) INT-RSVR実験}

TRIP と貯水池操作サブモデル、灌溉取水サブモデルを 両方利用して河川流量の計算を行ったものである。 

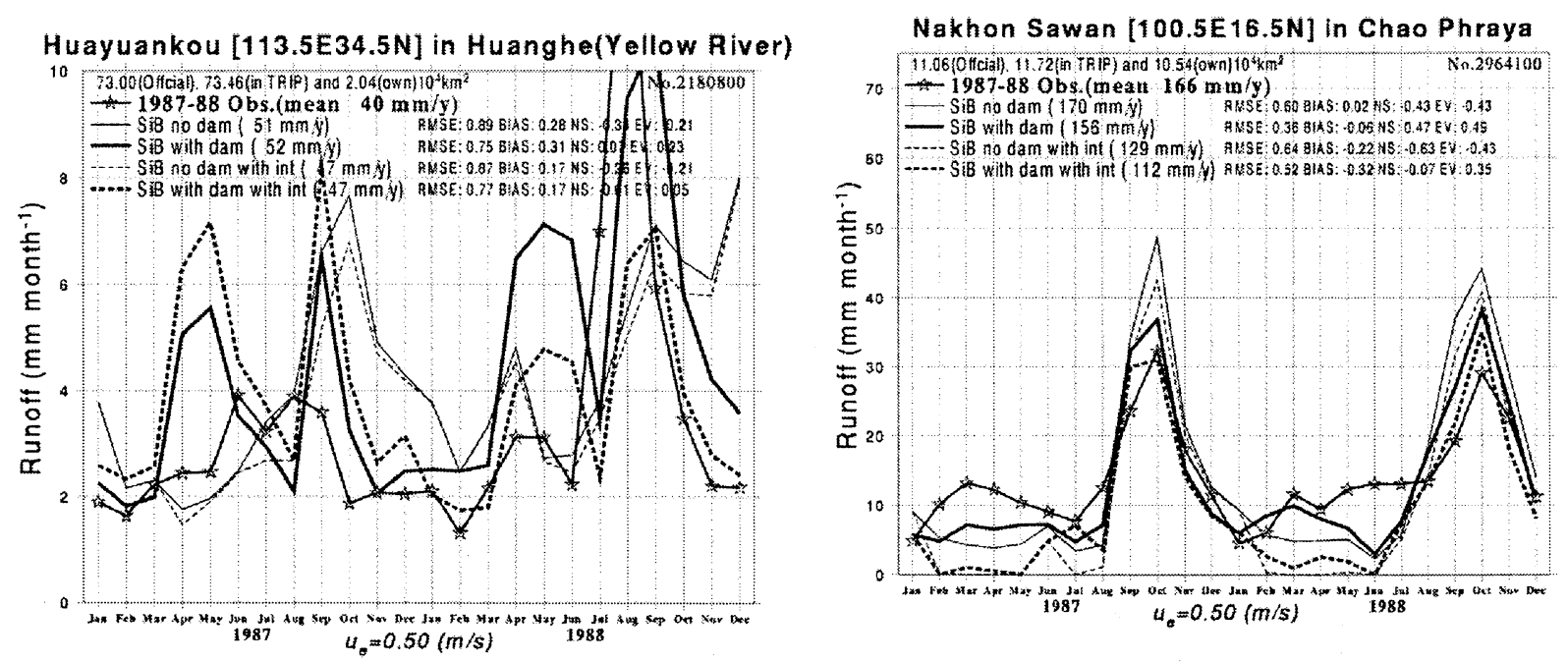

図-1 河川流量の比較（左 : Huang He川（黄河) Huayuankou（花園口）、右 : Chao Phraya川 Nakhon Sawan)

\section{（3）検証流域}

本研究ではHuang He川 (黄河) 、Nile川、Amu Darya 川、Sir Darya川、Colorado川 (アメリカ合衆国) 、 Chao Phraya川、Ganges川、Indus川、Euphrates川の 9 流域に着目する。これらの流域は灌夦農業が盛んな流 域であり、断流の発生が指摘されている河川でもある22。

\section{3. 結果}

\section{（1）河川水収支への影響}

まず各実験の1987年の全球の水収支を表-2に示す。 灌溉用水需要の計算值は $1413 \mathrm{~km}^{3} /$ yearであったが、本研 究で得られた取水可能量は貯水池がない場合で 649 $\mathrm{km}^{3} /$ year、ある場合でも $709 \mathrm{~km}^{3} /$ yearであり、需要量の 約 $50 \%$ に過ぎない。全球の年間の河川流量は世界の灌 溉用水需要よりはるかに大きいので、いかに水資源が 時間・空間的に偏在しているかを示しているといえよ う。今回考慮した世界の500の貯水池の操作によっても たらされる灌溉用水は $60 \mathrm{~km}^{3}$ と計算された。

表-2 各実験の水収支 $\left(\mathrm{km}^{3} / \mathrm{year} 、 1987\right.$ 年)

\begin{tabular}{|l|r|r|r|r|}
\hline & CTRL & RSVR & INT & INT-RSVR \\
\hline 流出量 & 30876 & 30876 & 30876 & 30876 \\
\hline 河口到達流量 & 30876 & 30936 & 30240 & 30153 \\
\hline 灌溉取水量 & 0 & 0 & 649 & 709 \\
\hline 河道内貯留変化 & 0 & -5 & -13 & -4 \\
\hline 浣水池賍留変化 & 0 & -55 & 0 & 18 \\
\hline
\end{tabular}

\section{（2）シミュレーション結果の検証}

計算期間である1987-1988年について観測值が入手で きた 2 地点について各実験のシミュレーション結果の 検証を行う。

a) Huang He川 (黄河) Huayuankou（花園口）

貯水池がない場合は 8 月から 11 月にかけて流量の
ピークが見られる。これに対して観測値の流量のピー クは 6 月から 9 月にかけて見られる。貯水池がある場 合は上流の貯水池（三門峡ダム、立目的は洪水調節） の操作の影響を受け、4月・5 月と 9 月に流量のピーク が現れている。これは前節のb) で推定されたHuang He 川下流域の農事暦が一期作は 8 月から 12 月、二期作 は 3 月から 7 月であり、これにあわせて放流が行われ ているためである。実際のこの流域では 6 月から 9 月 にかけてトウモロコシ、10月から5月にかけて冬小 麦が栽培されている（沈彦俊私信）。現在の農事暦推 定モデルは栽培期間を5ヶ月に固定し、気温が高いほ ど栽培適性を高く設定しているため、栽培期間が長く、 気温の低い冬をまたいで栽培される冬小麦を栽培する 地域で農事暦に誤差が大きい。

取水の影響は貯水池がない場合は単純な流量減少と なって現れる。しかし貯水池がある場合の87年は逆に 流量の増加という結果が得られた。貯水池の初期貯留 量は87年の 1 年分の流出データをモデルに繰り返し与 えて平衡に達したときの貯水池貯留量を利用している が、取水を考慮した際に貯水池一の流入量が変化し、 平衡状態が変わってしまったのである。

ここでは貯水池操作による流量ピーク再現性の向上、 取水による流量の過大評価の緩和の可能性は示唆され たが、本研究では河川流量、貯水池操作、灌溉取水の 各要素に不確実性があり、効果を明示できなかった。 農事暦と貯水池の初期貯留量に観測值を与えれば解析 もしやすく、再現性も上がると考えられるので、今後 の課題としたい。

b) Chao Phrayall Nakhon Sawan

貯水池の考慮の有無は花崎ら（2004）で詳しく論じ られたので取水の効果だけを考察する。87年は取水を 考慮すると貯水池の有無に関わらず、2 月から 5 月に かけて断流状態となる。この期間は乾季にあたり、灌 溉用水需要が極めて高く、流量観測地点上流で河川水 


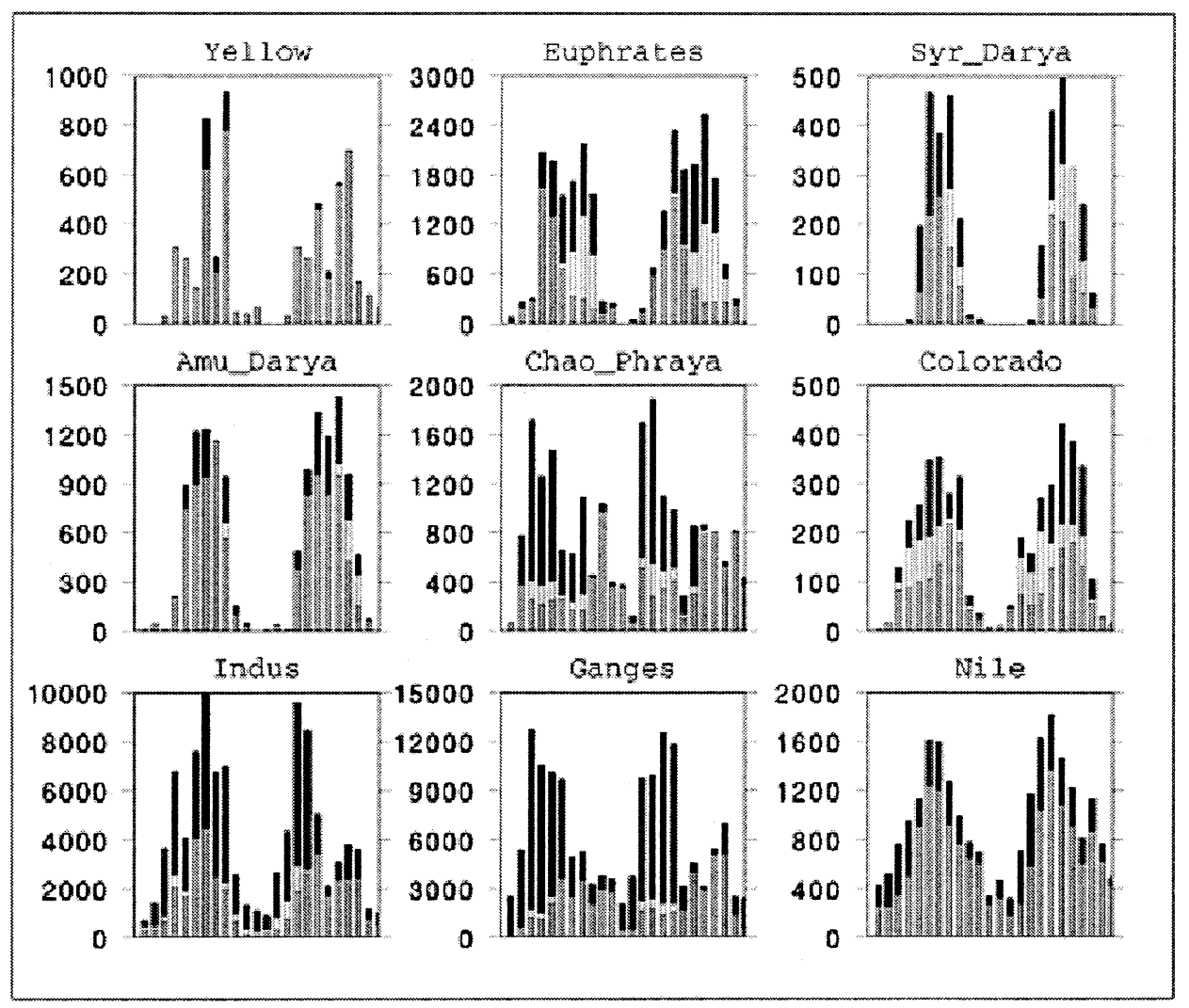

\section{図-2 流域の月別の灌溉用水需要と \\ 可能灌罆取水量 $\left(\mathrm{m}^{3} / \mathrm{s}\right)$ の時系列 (1987-1988)}

を取り尽くしてしまったからである。88年は貯水池が ある場合は断流こそ免れているが、観測值に比べれば 流量は極めて小さい。後述するとおり、この流域は乾 季に灌泊用水需要が可能灌溉取水量を大幅に上回る。 このような場合、現実の世界では当局が流域全体の需 給バランスを考慮し、作付面積を適宜コントロールし ている。取水量を算定する際にも同様の考慮が必要な ことが示唆された。

\section{（3）流域灌溉農業への影響}

次にモデルで推定された灌溉用水需要が同じくモデ ルで推定された河川流量により供給されうるかを需給 のタイミングと場所の両面から検討する。まず図-2に 示したのが流域の月別の灌溉用水需要量と可能灌溉取 水量の時系列を示したものである。黒のバーは流域の 月別の灌溉用水需要を、白のバーは同じく貯水池があ る場合の可能灌溉取水量を、グレーのバーは同じく貯 水池がない場合の可能灌溉取水量を示す。つまり黒の 部分が灌溉用水の不足を、白の部分が貯水池放流によ り取水可能になった量を示している。次に図-30左図 に示したのが年間のグリッド別の灌溉用水充足率（可 能灌溉取水量の灌溉用水需要量に対寸る割合）の空間 分布を示したものである。このとき、取水量、需要量 ともに月毎の累積值を計算している。プロットの大き
さはグリッドあたりの灌溉農地面積を表す。ただし、 $10 \mathrm{~km}^{2}$ 未満の場合は「十」と記した。プロットの色は灌溉 用水充足率を表す。色が濃いほど充足率が低く、水需 給が逼迫していることを示す。参考として既存の世界 水資源アセスメントで採られることが多かった取水を 考慮しない評価の結果も示した。図-3の右図は取水に よる流量の減少を考慮せずに流下計算を行い、各グ リッドの年平均河川流量の年平均灌溉用水需要量に対 する割合を空間分布で示したものである。

\section{a) 月別の需給バランス}

図-2よりTndus川、Ganges川、Chao Phraya 川や Euphrates川などで月によって需給バランスが大きく変 わるのが見られる。アジアモンスーン域に位置する三 流域では乾季にあたる 1 月から 6 月にかけて大きな灌 溉用水需要が発生している。ただしこのときの需要量 は全ての灌溉農地で作物の栽培に最適な量の水を与え て灌溉農業を行ったと仮定した場合の推定值であり、 現実には休耕地になって需要が発生しない場合も多い と考えられる。Fuphtrates川では融雪による出水が利 用できない 6 月から 9 月にかけて灌溉用水の不足が発 牛しているが、これは貯水池操作により相当緩和され る結果が示された。いずれの流域でも水需給が逼迫す るのは乾季作の行われる期間にとどまり、雨季作の行 われる期間にはそれほど深刻ではないことが示された。 


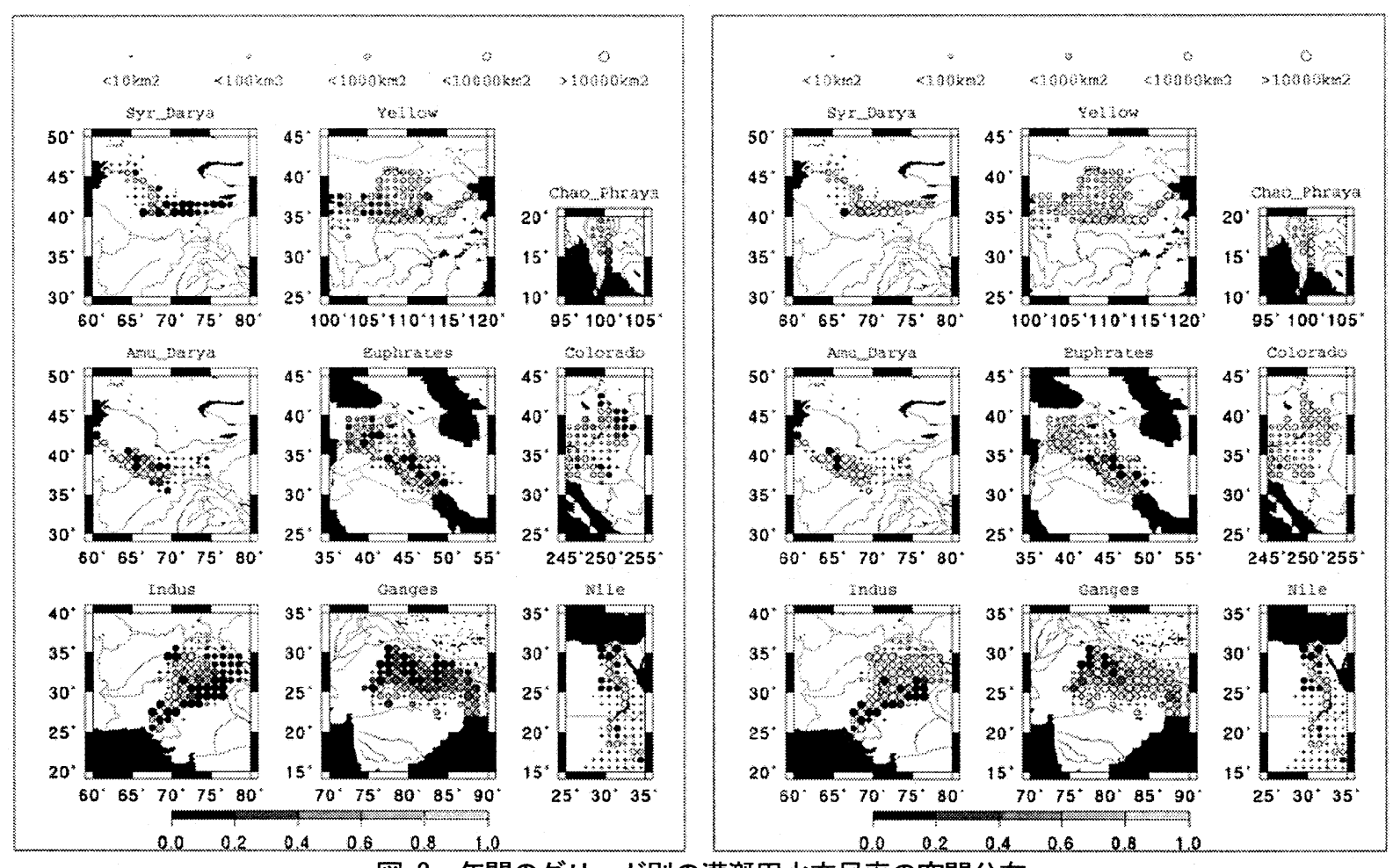

図-3 年間のグリッド別の灌溉用水充足率の空間分布

（左：取水を考慮 右 : 取水を考慮せず）

水需給の逼迫が懸念されているHuang He川とNile川 では年間を通じて灌溉用水の不足が生じないという意 外な結果が得られた。これには一つの理由が考えられ る。一つには本研究では水路によるグリッド外への導 水や河口デル夕地帯での流路の分岐を考慮していない ことである。グリッド外への分水が行われていれば、 需要量はより大きくなることが予想される。これにつ いては次節で論じる。二つにはNile川の特殊事情で、 流量計算值が観測值に比べてかなり過大になることで ある。Chan and Eagleson (1980)はWhite Nile川の流 量の60\%がBahr E1 Ghazalの湿地帯で蒸発により失われ ると報告しているが11)、現在利用しているモデルではこ のような流下途中の蒸発は考慮できず、下流の流量を 過大評価することになる。

Colorado川では年間を通じて貯水池による取水量増 加の効果が見られる。貯水池を考慮しない場合、この 流域では流量の時間変動が極めて大きいが、貯水池を 考慮した場合、流域に 9 つもる貯水池が年間流入量 を下流の需要に応じて再配分するため、大きな効果を 生んでいると考えられる。

b）グリッド別の需給バランス

まずは取水の考慮の有無について検討する。その違 いが最も顕著に現れているGanges川やChao Phraya川を 見ると、取水を考慮した左図では河口に向かうにつれ 充足率が下がっていく（グレーが増えていく）のに対 し、取水を考慮しない右図では充足率が下がっていな い(白のまま）。この現象は供給量に対する需要量の
割合が高いほど顕著に現れるため、水資源の評価を行 う上で極めて重要である。この現象は下流に限られた ものではなく、Huang He川、Euphrates川、Colorado川 では上流域に見られる。

次に前述した導水について考察する。本研究では河 川以外の水路による導水を考慮していない。このため たとえ本流のあるグリッドとは 1 グリッドずれただけ でも、本流から河川水が全く供給されないため充足率 が低くなる場合が見られる。図-3でIndus川やNile川で はこの例が見られる。これらのグリッドでは本流から 導水が行われていると考えるのが妥当であり、今後モ デルに取り組んでいく必要がある。本研究では持続可 能な水凅源に着目するため、降水を起源とにた流出の みで解析を行っている。このため帯水層の地下水（化 石水）に依存した灌賄地では供給量を過小評価する可 能性があるので注意が必要である。

最後に、本研究では灌溉効率 $100 \%$ の灌溉取水のみを考 慮したが、他にも灌溉配水途中のロスや生活用水や工 業用水の取水がある。灌溉效率が低い場合や大都市が ある場合には影響がより大きくなると考えられる。

\section{c）需給バランスの定義の違いに関する考察}

図-3の左図と右図にはもう一つ大きな違いがある。 左図も右図も灌漑用水の需要量は等しいが、供給量に は左図では年間可能取水量を、右図では年間河川流量 を利用している。左図は各月の灌溉需要に対する実際 の取水量が考慮されているので需要を上回った河川流 
量は供給量に含まれない。しかし右図は需要を上回っ た河川流量も供給量に含まれることになる。この影響 はChao Phraya川を見ると顕著である。図-1右図や図-2 を見れば明らかなように、この流域では乾季に流量が 少なく、灌泊用水需給が逼迫し、逆に雨季には流量が 豊富で灌溉需要が少なく、灌溉用水に余剩が発生して いる。しかし図-3の右図の方法では雨季の余剩分と乾 季の不足分が相殺され、河川水が乾季と雨季を合わせ た灌漑用水量をまかなえるという誤った情報を示して いる。

\section{5. 結論と今後の課題}

冒頭に挙げた目的に対し以下のような考察が得られ た。第一に世界の可能灌溉取水量は貯水池を考慮した 場合 $709 \mathrm{~km}^{3}$ 、考慮しない場合 $649 \mathrm{~km}^{3}$ と推定された。これ は花崎ら（2004）により見積もられた全球の灌溉需要 量 $1413 \mathrm{~km}^{3}$ の約 $50 \%$ にすぎない。流量シミュレーションの 精度の影響も考えられるが、花崎ら (2004) は取水可能 性のない灌泊用水を多量に灌溉需要推定に含めている 可能性があり、灌溉需要量の推定に流域の水需給バラ ンスを考慮する必要が示唆された。なお貯水池操作に より可能取水量は $10 \%$ 程度上昇するという結果が得られ、 需給バランスを論じる際に貯水池が果たす役割が大き いことが示された。

第二に灌溉取水を考慮することによるシミュレー ションの再現性の向上の可能性に関しては結論を得る ことができなかった。Huang He川では推定された農事 暦と現実の農事暦にずれがあり、農事暦が取水と貯水 池操作に大きな影響を持つことから検証を続けること ができなくなった。モデルによる農事暦の推定は文献 が入手できない地域にも適用できるという利点がある が、シミュレーションの根幹に関わるため、空間解像 度や時間解像度を下げても観測べースのものを使う必 要が示唆された。Chao Phrayaでの検証では乾季の取水 量が過大に見積もられていることが明らかになった。 ここでも、上述の通り、灌溉需要の推定に際し、水需 給バランスを組み込む必要があることが示された。

第三に月単位の灌溉用水の需給バランスであるが、 本研究が扱った 9 つの流域では雨季作の灌溉用水需要 はおおむ齐河川水によって供給できるという結果が得 られた。乾季作の灌泊用水の不足量は流域差があるが、 雨季作よりもはるかに大きい。水資源アセスメントを 行う際はこの渇水期の評価に重点が置かれるべきであ ることを強調したい。需給バランスに果たす貯水池の 効果は特にEuphrates川、Colorado川で顕著なことが示
された。ただしこれらの結果には導水やデルタでの河 道分岐による灌泊流域の拡大、灌溉以外の取水、配水 中のロスなどが考慮されず、現実の影響はより大きい と考えられた。最後に取水の考慮の有無、および年単 位の評価と月単位の評価を比較し、水資源の評価に取 水の考慮と年単位以下の評価が重要であることを示し た。

謝辞: 本研究は科学技術振興事業団戦略的基礎研究推 進事業「人間活動を考慮した世界水循環水資源モデ ル」（代表：沖大幹）の成果の一部です。有益なコメ ントを下さった査読者の方に感謝いたします。

\section{参考文献}

1) Shiklomanov, I. A.: .Appraisal and assessment of world water resources. Water International, 25(1), pp11-32, 2000

2) Postel, S.: Pillar of sand, Norton \& Company, 1999

3) Haddeland, I. Lettenmaier, D. P. and Skaugen, T.: Effects of irrigation on the water and energy balances of the Colorado and Mekong river basins. J. of Hydrol, (submitted)

4) 甲山治、田中賢治、池淵修一: 中国淮河流域におけ る農業形態の推定と陸面過程モデルへの適用、水工 学論文集、Vol. 48、pp.211-216、2004

5) Döll, P and Siebert, S.: Global modeling of irrigation water requirements. WRR, 38(4), 2002

6) Alcamo, J., Döll, P., Henrichs, T., Kaspar, F. Lehner, B., Rösch T. and Siebert, S.: Development and testing of the WaterGAP 2 global model of water use and availability, Hydrol. Sci. J., Vol 48(3), pp317-337, 2003

7) Oki, T. and Sud, Y. C. Design of Total runoff integrating pathways (TRIP) -A global river channel network. Earth Interactions, Vol.2, 1999. http://EarthInteractions.org

8) 花崎直太、鼎信次郎、沖大幹 : 貯水池操作が全球の 河川流量に与える影響の評価、水下学論文集、Vol.48、 pp.463-468、2004.

9) WRI (World Resources Institute) 1998-99 World Resources. Report of UNEP, UNDP \& World Bank. Oxford University Press, Oxford, UK

10) Dirmeyer, P. A. Dolman, A. J. and Sato, N. The pilot phase of the global soil wetness project, Bull. Amer. Meteor. Soc., Vol.80, pp.851-878, 1999.

11) Chan, S. -O. and Eagleson, P.S.: Water balance studies of the Bahr El Ghazal Swamp. Rep. No. 161, Ralph M. Parsons Lab. Water Resources. Hydrodynamics, MIT, 1980

(2004.9. 30 受付) 